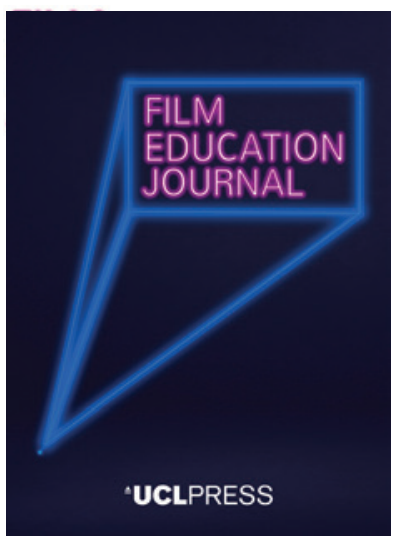

UCLPRESS

FILM EDUCATION JOURNAL

ISSN 2515-7086 (Online)

Journal homepage:

https://www.uclpress.co.uk/pages/film-education-journal

\title{
Triangulating a discussion between film, the viewer and a wider frame of life: Reflections on a life in film education
}

Mirjana Borčić

\section{How to cite this article}

Borčić, M. (2020) 'Triangulating a discussion between film, the viewer and a wider frame of life: Reflections on a life in film education'. Film Education Journal, 3 (1), 32-45. https://doi.org/10.14324/FEJ.03.1.03

Submission date: 1 September 2019

Acceptance date: 31 January 2020

Publication date: 23 June 2020

\section{Peer review}

This article has been peer reviewed through the journal's standard double-blind peer review, where both the reviewers and authors are anonymized during review.

\section{Copyright}

(C) 2020 Borčić. This is an Open Access article distributed under the terms of the Creative Commons Attribution Licence (CC BY) 4.0 https://creativecommons.org/licenses/by/4.0/, which permits unrestricted use, distribution and reproduction in any medium, provided the original author and source are credited.

\section{Open access}

The Film Education Journal is a peer-reviewed open-access journal. 


\title{
Triangulating a discussion between film, the viewer and a wider frame of life: Reflections on a life in film education
}

\section{Mirjana Borčić*}

First published in Odstiranje pogleda: Spomini, izkušnje, spoznanja (Borčić, 2014)

Translated from Slovenian by Sunčan Stone

\begin{abstract}
In this article, Mirjana Borčić - one of the foremost voices within Slovenian film pedagogy - reflects upon an international life within film education on both a practical and a theoretical level. A particular focus is placed upon the central role of discussion within film education, in shaping and developing the subjective experiences young people have of watching cinema. Finally, some concrete proposals are shared as to how one might best approach a classroom-based discussion with young people, centred around the experience of watching films.
\end{abstract}

Keywords: film education; discussing film; Slovenia; Europe

\section{Introduction by Petra Slatinšek ${ }^{\star *}$ and Jamie Chambers}

Mirjana Borčić is one of the foremost figures within Slovenian film education. She has been a central part of the development of both the theory and practice of film education in first Yugoslavian and subsequently Slovenian film education since their respective inceptions (see Slatinšek, 2020). The books and articles Borčić has published on film education have proved influential to the extent that, when a national film educational programme was created by Kinodvor Cinema in 2008, it was her work that served to underpin and inform its fundamental aims and objectives. Indeed, within the comparisons between national histories of development in Slovenia and France made by Petra Slatinšek elsewhere in this issue of the Film Education Journal (Slatinšek, 2020), Borčić may be considered a figure of similar stature to Alain Bergala, a film pedagogue whose intervention into the national film education strategy has proved formative and foundational. This contribution to the Film Education Journal comprises a series of extracts from Borčićs book, Odstiranje pogleda: Spomini, izkušnje, spoznanja, published by Kinodvor Cinema and Slovenian Cinematheque in Ljubljana in 2014 (Borčić, 2014). The extracts were initially selected by Kinodvor with the close participation and blessing of Borčić and her grandson Sunčan Stone (who here acted as a translator) and have been gently edited by the editors of the Film Education Journal for shape and continuity. In particular the excerpts explore theories of the importance of free, explorative discussion in the fostering of new experiences of cinema, and how exactly one might go about starting such a discussion. Today, Borčićs ideas remain as lucid and useful for contemporary pedagogies of film as they were initially, and we hope that, in making them now available for English-language 
speakers, they will continue to provide a source of inspiration and discussion beyond the initial, crucial conversations they sparked in Slovenia.

\section{Extract 1 - Paving the path to youth film culture}

When I started working in the field of film education, I at first applied the same methodologies in studying films that I was taught by my professors of pedagogy and that I picked up during my study of literature and language. At this time, my approach to film education did not significantly differ from my approach to studying literature. I slowly came to realize, however, that the two cannot be taught in the same way and that film is primarily a visual art form, meaning that the perception of a film is completely different from the perception of a literary work, even though we can find numerous similarities on a dramaturgical level. Film's means of expression are unique, and we must thus look for new ways to bring film into closer connection with potential viewers. Even the mere act of watching a film demands a different, more intense attention than the experience of literature. Film scenes rush in front of our eyes in quick succession, without any chance of returning. As a result, understanding of plot depends on a viewer's capacity for observation, their capability of linking different aspects of what is seen into the sense of a whole, and the associations that pop up for them while watching.

It is my belief that the meaning and purpose of film education lie in developing these capabilities, and that doing so can lead to better experiences of film. Such an approach also looks to free young individuals of prejudices, and reduces the possibility for them to be manipulated, as well as helping them to develop their sensitivity for the language of film, all of which are primary tasks of film education. How can this be achieved? I knew that there was no single way. One has to be aware that every viewer experiences a film in a unique way: a film projected in a cinema with one hundred people will have one hundred interpretations. If we want every individual to enrich their own experience of the film through contact with the experiences of their fellow viewers, a dialogue needs to be established. Discussing a film is not the same as explaining a film: it is a search for meaning that avoids generalization and encourages creative thinking. My experience has shown that when discussing a film, pedagogues often resort to generalized explanations, which aim to teach rather than to discuss, and that this in turn can lead students to blindly accept values without considering them. The consequences of such an approach can be horrendous. If viewers mechanically accept other people's opinions, they may start believing that they themselves know nothing and are not capable of producing original thoughts on the film.

More considered approaches to film education can put a stop to this and teach the young individual that they are capable of thinking independently about a film. This is a long-term process, in which the teacher plays a crucial role, for it is the teacher who directs the young viewer and encourages them to form an attitude to what they have seen. One needs to take into account here, however, that nobody has the power of knowing what is going on within the mind of another person. While I wanted viewers to react independently to film content, I was fully aware that it would not be easy to achieve this independence without developing the habit of creatively watching films, learning how to follow unique film language, being sensitive to the events and relationships surrounding the viewer and connecting these to film. Beyond these aspects, the way in which we perceive a film also depends on our world view, upbringing, knowledge, film experience and current mood, as well as on what we experienced before we went to the cinema, and what we talked about with our friends just before the film started. Unexpected associations influence the way we interpret a film. It therefore depends 
on the skills of the person leading the discussion, how participants connect their associations to the film that they have just watched and, while doing so, how far they are able to stick to the actual content of the film.

At a certain point I understood that the true interest of film education is in how one experiences film. Experiencing a film is an active process between what is communicated by the film-maker and what is experienced by the viewer, which then expands the latter's world of experiences. It is for these reasons that film education should encourage intense experiences of film and create the conditions for the independent formation of aesthetic, ethical and social values. Only a film-literate viewer, who fully comprehends the uniqueness of film expression, is capable of considering and understanding the artistic value of a film. This viewer is capable of grasping the contents of a film faster and with less effort, while adopting a critical stance towards the film, and this serves to condition their independent interpretation of what they experienced while expanding their value system.

Film education can be wrongly understood as teaching film language, the history of film and manners of film production. Of course, one has to be acquainted with the basic ways in which film expresses itself, the history of film and know how a film is made. As the art of education lies in steadily introducing new aspects of knowledge, I tried to ascertain when and in what way I should pass on this basic information in order for it not to become an end in itself. When reviewing certain previously introduced curricula for teaching film, which introduced aspects of film terminology such as 'shot', 'crew' and 'edit' to students in lower classes, I decided to avoid this. My thoughts led me to develop a method for discussing film that was very close to the method used to discuss works of literature introduced in the early 1950s. I succeeded only to a certain degree, for such an undertaking was not as simple as I had imagined. The traditional pedagogical approach to works of literature was the first obstacle in my path. My students were used to being given an explanation of the contents of a work of art, and thus not having to search for its meaning themselves. I also had my own problems, for I often caught myself - and still do - trying to force my own opinions and interpretations upon others. I was wandering through a labyrinth between what I had learnt until then and the way I thought a work of art should be addressed.

I had reached a crossroads and needed to choose a path, and in this moment I was helped by my students. Whenever I followed the instructions of established pedagogues, I moved further away from young people. I felt that an approach to film education that included explaining the plot of a film was futile. I realized that explaining the value of an individual film is not the way to go, and that I had to avoid this. As I started teaching film education in a film club, in which my contacts with students were more relaxed, I managed to get closer to the way in which they experienced film, and life in general. I was interested in the way in which they established certain measures, and how they then included these in their own ethical, moral and social value systems. I became aware that such a conversation makes sense only when all participants, including myself, are looking for the meaning of the content.

Due to its moving images, film's depiction of reality can be extremely convincing. The author of a film adds their imagination, which gives the reality they are depicting a new dimension, and in the phase of interpretation, the viewer adds their film and life experiences to what they have just seen. As a result, the acceptance of the apparent reality depends on the inclinations of the individual, as well as on their capacity for creative thought and independent evaluation. This should be the natural path to recognizing values. Once viewers start watching films without critically evaluating them, they can become easily manipulated. 
Film education should thus encourage independent critical thought. There are infinite ways of reaching this objective, starting with the simple viewing of a film in a cinema or at home, and reaching all the way to organized film education. Gathering experience starts at an early age. Research into the perception of film carried out twenty years ago included toddlers between 1 and 3 years of age, research that has proven to be worthwhile. Learning one's mother tongue is similar to learning film language simply through watching. Basic understanding comes naturally, but one needs to invest a certain degree of effort in order to understand what is on offer beyond this basic understanding. In order for the viewer to be prepared for the active experience of film, for applying meaning to what is seen, they need to become film literate. Without this film literacy, there is no real fun, broadening of the horizons or catharsis.

This was the real reason why I began my work with film education. I gained my first experience during young people's leisure time, and here I faced a challenge: how can I make young film enthusiasts start watching films with an open mind? While these young people joined the group having aspects of previous personal experience, I knew that their experience needed to be supplemented by the experience of others. An individual should be ready to compare different experiences, and to take from them whatever is acceptable to them.

As soon as I realized the importance of film experience, I eagerly began to consider the perception of film. I wanted to gauge the responses of the students. I wanted to know how film form influenced the way they followed a plot. My assumption that viewers begin to understand film language by watching films was quickly confirmed. By learning to understand film language, viewers become more susceptible to the messages in a film and more capable of including its information in their world of experience. Experience has taught me that it is watching films that is the most important thing in order to learn film language, and that enriching this experience with the necessary aspects of knowledge is the main goal of film education.

Watching films is thus the basic, easiest and quickest way of learning film language. Pedagogues, psychologists and sociologists are all aware that this is the easiest and also the most efficient way. The first organized intervention into children's viewing experiences had already taken place at the end of the First World War. The goals behind this intervention varied: from defending European children from the invasion of American ideas, to passing on information about the relationships between people at a level understandable to children, to developing a critical attitude to media content and values. When the demand for film literacy spread around the world during the 1970s, the desire for an organized and planned approach came to the forefront, and different institutions and environments responded in different ways.

\section{Extract 2 - The European experience and beyond}

When I took over the Department of Film Education in Pionirski dom ${ }^{1}$ in Ljubljana in the mid-1960s, I began a new, professionalized period in my role as a film pedagogue. This new role demanded deeper knowledge. At that time, Jovita Podgornik, a university professor (and later an editor at TV Slovenia), was well established in European film education circles. On her suggestion, I was invited to a conference taking place as part of the International Film Festival in Mannheim, at which pedagogues, sociologists, psychologists, film-makers and theoreticians discussed issues related to film education. I was subsequently a regular attendee at this conference for more than fifteen years, and much of my thinking on film and film education was formed by the various interpretations, forms and methods discussed within this circle of experts. Similarly to 
the way in which the Mannheim Festival defined its mission in establishing a bridge between the East and the West, this conference felt that a key role of film education was in eliminating prejudices, bringing people of different beliefs closer together and encouraging young people to engage with difference.

The beginning of my professional film education career was marked by a seminar lasting several weeks organized by the Federation of Film Clubs from Poland. The Film Advisory Committee sent Branko Šömen and myself to learn how these film clubs operated and to gauge the atmosphere that favoured and supported films, the atmosphere in which Adrzej Wajda, Jerzy Skolimowski and Andrzej Munk worked. I will never forget my discussions with Danuta Palczewska, an activist of the federation, on the necessity of sensitizing the viewer. Dr Janina Koblewska-Wróblowa, a professor of pedagogy at Warsaw University, told me in great detail about research into the child film spectator. As the editor of film publications at Prosvetni servis, I included her book Film i dzieci (Child and Film), based on this research, in the Seventh Art series.

Roughly at the same time that I started to disseminate my own thoughts on film education, Vitko Musek, the president of the Film Advisory Committee at the Association of Educational Workers of Slovenia, sent me to the International Film Festival for Children and Youth in Gottwaldov. ${ }^{2}$ Dušan Makavejev, Miljenko Karanović and Slobodan Novaković, who represented the Committee of Film and Children at the Council of Associations for the Protection of Children and Youth in Yugoslavia, were already there. Through their contacts and acquaintances, they helped me become part of the European movement for young people's film culture of youth, making my participation at the festival worthwhile. Zvone Miklavič, the director of Pionirski dom, believed that an international conference in Ljubljana would encourage the development of film education in Slovenia and wanted me to use my presence at the festival to discuss the possibilities of realizing his ideas with other festival participants. He also authorized me to ask whomever I believed was appropriate whether they would be prepared to support our endeavours in their reports. This was how the foundations were laid for the 1964 conference on approaches to film education, an extremely important event within the history of Slovenian film education. The responses we received demonstrated that the conference had been a great success, and the Department for Film Education at Pionirski dom subsequently became an active member of the International Center of Film for Children and Young People (CIFEJ), an organization connecting various movements working towards the promotion of youth film culture all over the world. We were all performing pioneering work, and we wanted to reach our goal as soon as possible. This resulted in an efficient and successful exchange of programmes and materials. There were plenty of experts who were prepared to explain their approach and the results of their research. We became a large family, and we were connected by an infinite sense of solidarity. We made the best of every opportunity to meet personally, and when this was not possible, we would exchange letters.

It became a habit of mine to take advantage of my visits to my daughter (who at the time lived in London) to visit the Department of Film Education at the British Film Institute (BFI). Every time I visited London, Henry Geddes, head of this department and a participant at the Ljubljana conference (and at the time the president of CIFEJ), prepared a programme through which he updated me regarding novelties in the field. Around this time, the BFI began discussing a thorough audiovisual approach to film education, and made sure not to neglect child and youth creativity in these discussions. While Henry was neither a practitioner nor a researcher, he was a renowned expert on 
film education and an excellent organizer from whom I learnt a great deal, and whose teachings I later incorporated - albeit in an adapted form - at Pionirski dom.

Geddes' young co-worker Jim Hillier totally overwhelmed me with his approach to film education, which at the BFI was expanded to include television, and consequently called screen education. Hillier researched how to make a young individual understand the importance of images and learn how to connect different meanings. He created special exercises, which, through the observation and interpretation of photographs, comics, films and videos, led to the understanding of moving pictures. Similar exercises were also prepared by the Dutch Institute of Film and Youth. With these initiatives, the two institutes led the breakthrough of the visual into film education. To a certain degree, they abandoned the method of retelling the plot and placed previous moralizing concerning the idea of the film in the background. They were developing a method that encouraged visual thinking. The perception of form and its influence on the individual's experience of film moved to the forefront. This was a film awareness project - not only for children, but also for the teachers and pedagogues, and further research into the methods of film education for young people in and outside classrooms became a pedagogic necessity.

Jean-Pierre Golay led the Centre for Audio-Visual Education in the Swiss town of Lausanne. He approached film education primarily from the aspect of creativity. The Swiss financial situation made it possible for him to visit almost every village with his studio on four wheels, equipped with 40 S-8 cameras and editing tables, giving the opportunity for every student within a classroom to create their own film. While he also included comics, photographs and illustrations as subjects of study, he was mainly interested in film, including animation. Similar to the work of Tone Rački in Slovenia, Golay saw the encouragement of children's creativity through animated film as an excellent transition from children's drawings to moving pictures. Children like to draw and paint, and then they go through a period in which they are interested in movement; in time they start thinking in terms of moving pictures and looking for their meaning. He considered this search for meaning to be the most important element, and capturing children's experiences of the world became the primary guideline for these courses. In the creation of a film, children were given full independence throughout the creative process - from writing the script to editing the film and creating the soundtrack. Golay's courses were almost always attended by an entire class of approximately forty students. Here, in terms of approaches to working with a film camera in a classroom setting, there seemed to be only two available options: either to give the children instructions as to what they are allowed to do and what not, or to just let them do their thing. Golay decided to let them do what they wanted to do. Children who were experienced television viewers jumped at the opportunity, and demonstrated that they were capable of being creative and original. Golay might have suggested that his students avoid mimicry, and that they should instead find their own themes and express them in their own ways. Regardless of whether he interfered or not, it is important that he offered children the opportunity to create something personal with a film camera. Today, as almost every child carries a film camera in their pocket, I like to remember his principle. He was an exceptional colleague and he regularly updated me on his work. We have published some of his articles in Ekran and in the series Filmska in TV šola (Film and TV School), in which he - instead of describing his organizational work decided to focus on his conclusions as to how young viewers process and interpret films.

In the period prior to the disintegration of Yugoslavia, I was the president of the Yugoslav committee Film and Youth, which operated within the Film Institute in Belgrade. In order to appropriately carry out the task that I had accepted, I needed to establish a strong working relationship with CIFEJ. By this point, previous occasional 
acquaintances had become permanent co-workers, and some of them even became my friends. We were like a large family, always ready to cooperate and support any interesting ideas, no matter from where they emerged.

In the 1970s, the Film and Child Center in New York invited me to attend a conference, at which I presented the activities of Slovenian films for children. The Film and Child Center was led by Maureen Gaffney and her right-hand woman DeeDee Halleck, a documentary film-maker, both of whom were part of the circle of independent New York cineastes. Maureen was not merely a good organizer; she was also an important expert in the field of film and film education. Her ideas as to what constitutes a film for children were based on experience and research. She had interesting ideas regarding the young film viewer and liked to assert them in her work. She strongly opposed the Disney school, which influences children with its stereotypes, and fails to open the doors to what is newly emerging - whether in life or in film.

The situation in Iran was very different. In the early 1970s, the Institute for the Intellectual Development of Children and Youth was led by Shahbanu Farah Pahlavi (née Diba), who I had previously encountered on the jury of the Children's Film Festival in Venice. Pahlavi told me about the activities of the institute, and asked me about the possibility of a Yugoslav child participating in the children's jury at the Festival of Films for Children in Teheran, an offer that, of course, I accepted. When the official invitation arrived, we decided to organize the Yugoslav selection for the child jury member, and asked each of the republics and autonomous provinces to come forward with their representative, who should be reasonably fluent in English and have a well-developed sense for film. We formed a group that, during the annual overview of Yugoslav films created by children, would select the appropriate representative. Unfortunately, only Croatia, Vojvodina and Slovenia responded. A boy was selected; I only remember his surname - Adamič. He was a member of the language course at Pionirski dom in Ljubljana, and, when tested, he showed exceptional sensitivity for film expression and capability for evaluating films. I was appointed as his chaperone, and the Iranians asked me to prepare information on our work, which I would share with the participants of a conference that formed part of the festival.

My stay in Teheran did not revolve merely around the festival. We were given the opportunity to learn about the various forms of cultural education for young people. The official belief at the time was that intense education of young people was necessary if they wished to ensure the intellectual and cultural development of the nation. For these reasons, the associates of the institute did not study cultural education merely within the study curricula, but also researched the possibilities of informal cultural education in children's leisure time. They established a network of cultural centres for children. There were over forty centres already in the southern, less-developed part of Teheran, which were open for children walking in off the street. They consisted of somewhat larger premises, which were not purpose-built for cultural activities, but were renovated to fit their needs. In the forefront of these centres were a library and a reading room, in which children would read, or sometimes merely flip through the books on the shelves. I would like to mention that at the time an Iranian illustrated children's book was experiencing great global success, and when I saw how popular it was among the children, I was convinced of its originality. Children came to play in this space, which included the library. Whenever they wanted to, they could come here and draw, make films or create music with simple traditional instruments, serving the same purpose as the Orff approach in Yugoslavia. While the library was primarily a shelter for children from the streets, it unobtrusively also offered the possibility of getting involved in creative groups led by trained tutors. The groups were governed 
by spontaneity, and would meet by arrangement and not according to a timetable. Even before I arrived in Iran, I was acquainted with the films that were created by Iranian children and youth, and they participated in the competition organized every year by CIFEJ. I was overwhelmed by the contents and originality of the films created by Iranian children, and was totally taken by surprise when I realized how easy it was to convince a child to make a film that fitted their soul.

Iran also had a showcase cultural centre for children, similar to that in the Soviet Union, which operated under the patronage of the shahbanu in the park under her castle. I found the building, and the equipment available in this centre, to be remarkable, and here American mentors adjusted their methods to fit Iranian youth. Regardless of the splendour and, for us, unavailable possibilities represented by this showcase cultural centre, I believed that the right path to film culture could be found in the centres in the south of the city.

The Moscow Central Pionirski dom had a miniature professional film studio with professional cameras, editing desks and spotlights. In this studio, children played at being a film crew and, together with professionals, they would create scripts and storyboards, record, edit and equip films with sound. They learnt how to make a film. While playing, they imitated the film production process and learnt a great deal about how a film is made. Even though they obtained knowledge on how films were made while having fun, they did not get sufficient opportunity to experience the hidden aspects of creativity that make individuals respond actively to life. I discussed this with Kira Paramona, a professor of dramaturgy at the Moscow Film Academy and the president of the CIFEJ branch in the Soviet Union. Even though we were personally close, we could not find common ground on numerous issues. She did not understand that I was from Yugoslavia and thus did not belong to any bloc. She often behaved like an older sister and drew attention to my Slavic roots, my study of Russian language and the shared struggle during the Second World War, and I would also receive invitations to the preparatory meetings of the Eastern Bloc general assemblies of CIFEJ. She never got completely involved with our broad film education family, which was held together by our passion for film and young people, rather than by politics.

Professors Ilja Frez and Ilja Weisfeld, both of whom worked at the same academy, were completely different. The director Ilja Frez appeared on my radar with his film for children Ya kupil papu (I Bought Daddy, 1963), which I had seen as part of the regular programme in the Ljubljana cinema Komuna. Soon afterwards, Pionirski dom in Belgrade, which organized an international screening of films for children during its festival, sent a package of three Soviet films for children as part of its international exchange. This small package of films included Ya kupil papu, and the director of the film was invited to Ljubljana. As the film was playful and lively, I was expecting a young man rather than a white-haired man of noble appearance. I quickly overcame my surprise, as I soon realized the depth of his knowledge, his devotion to film and his commitment to young people. By coincidence, this meeting coincided with a request passed on by Reiner Keller, who until then had failed to successfully invite a film practitioner from the Soviet Union to the Mannheim film education conference. Keller asked me if I knew anyone from the Soviet Union who would be interested in joining our community. Ilija Frez agreed, and an official invitation from Mannheim soon followed. A few years later, he was replaced by Ilja Weisfeld, a professor of the history of film at the same academy. I continued to meet Ilija Frez in Mannheim and Moscow over a period of several years. He was a man of unique sensibility, a dreamer and an intellectual. Our conversations were spontaneous, and did not take place on an operative or on a political level. These conversations made me feel the true pulse of the life for film. Frez had his way of 
thinking, which opened up a number of questions. Usually I did not grasp this during our conversation, and it was only once I returned home that the questions came into my full consciousness and I had to address them, for which I remain truly grateful. I liked meeting new people, getting to know their ideas and the paths that led towards the fulfilment of their plans. Every person I met taught me something and, if nothing else, I learnt what I should avoid.

\section{Extract 3 - Introduction to understanding film}

In the 1960s, film's image changed drastically, beginning to introduce numerous novelties in appearance and content, thus demanding greater attention and creative thinking from viewers. The subsequent realization that understanding the meaning of an individual film is more important than a dry programme of learning centred on the rules of film language and film history led to important changes in approaches to film education. Many teachers and pedagogues started abandoning teaching film theory, and focused on developing sensitivity towards how film expresses itself. I also stopped teaching film theory and consciously abandoned my original concept. Instead of teaching film theory, I chose to follow a path to understanding film by emphasizing viewers' perception of a work of art and their reaction to it.

In my endeavours to elevate film culture, I focused more on discovering the meaning of the film through experience, rather than learning facts about film. I focused on viewers' experiences of film, which led to new experiences of both film and life. I dedicated my work to developing viewers' capabilities of understanding films. I encountered numerous methods. Because I believed in a relaxed discussion, which took into account and respected the experiences of the participants, I avoided setting up lessons in advance. While prepared conversation patterns would certainly simplify preparations for teachers, they would also allow the possibility of attention drifting from discussing the experience of watching the film towards merely accepting the explanations prepared in advance. Diverting attention from the participants' experience to the teacher's attitude to the film could thus limit the views of the participants in the discussion and move the discussion away from the content of the film.

I decided to present my approach to teachers of the lower classes in primary schools, as well as to the teachers of Slovenian language in the higher classes of primary schools. I prepared the programme for a one-day seminar, taking into account the demands of the curriculum. With the help of Petra Dobrila, adviser for the Slovenian language at the Institute for Education, I then implemented this programme weekly, over a period spanning more than one academic year, each time in a different town. I decided to systematically present a lesson that was not based on teaching facts. The idea behind this presentation was to discover a viewer's experience of a given film and their attitude towards its content. As I wished to introduce the participants in the seminars to the nuances of pupils' experiences of film, I based the seminar on watching a film a number of times, as well as on holding multiple discussions.

The seminar took place on two levels. First, the teachers watched and discussed the film. Then we repeated the screening of the film and the discussion, this time with their pupils. The teachers observed the reactions of the children. As they had already seen the film as well as discussed it, it was easier for them to observe and understand the responses of the children. The more relaxed nature of the children often helped them find a short cut to understanding the essence of the film, enabling a more relaxed experience of the film's content, which thus opened better possibilities for expanding 
their view of the world. The lively discussion, which was not dominated by more confident individuals, illustrated the advantages of this approach over an approach that merely sought to pass on facts. I thought it was necessary for participants to see the film again at the end of the seminar. The aim of this screening was to deepen their impressions and to strengthen the realization that every viewer, whether a pupil or teacher, sees their version of the film, creates their experience and strengthens their attitude towards the world. The way in which we discuss film became the subject of my study. I passed on my findings to my colleagues at the department. I am convinced that their pedagogic experience, independently of mine, enriched my work in important ways on a daily basis.

\section{Extract 4 - How to discuss film}

A discussion about a film enables the film to be interpreted within a group. The pupils begin with their film-based and social experiences and use the skills that they have gained through the practice of observation, connection and selection. The discussion encourages them to directly and in an organized manner achieve the educational goals as defined in the curriculum for film and television education in Slovenian primary schools. For lower stages of primary education, these discussions about film are more about helping students to understand films, rather than about educating them.

The didactic aim of the discussion depends on the curriculum. The teacher should ask of the pupils slightly more than they are capable of. This elevates their inquisitiveness and their desire to discover the unknown relations of a film, as well as its ethical, moral and social nature. One needs to ensure, however, that the set standard of the discussion does not surpass the pupils' capabilities. If the target is set too high, participants will lose the will to cooperate, which will change the situation and force the teacher or leader of the discussion to explain the film as they experienced it. In this way, the cooperation of the pupils, which should be evident in their desire to research and discover new things, is automatically brought to an end.

The debate about the film should reveal the experiences of students that emerged while they were watching the film, and that created special emotional and mental moods that influenced the way in which they engaged with the film. This depends on the circumstances in which young viewers watch a given film, and on their level of maturity.

To experience a film means to understand the film's plot and actively incorporate it into one's cognitive world; it is a form of communication within which we seek the meaning of what we have observed and try to decipher the meaning of the author's messages. The experience emerges and is formed already while watching the film, but it is expanded upon during the later discussion; it is a meeting between the viewer's experience and the experience offered by the film.

Such discussions about a film enable viewers to become aware of their experiences, to check their feelings, thoughts and viewpoints, and to incorporate the message of the film into their life experience, form their measures for evaluating films and potentially lead to a new aspect of revelation.

The discussion can be about a film that the pupils watched on television, in a cinema, during school hours or at a meeting of a film club. We rarely reach for films that participants in the debate saw a few days earlier. Nowadays everybody watches television almost every day, so new visual impressions are constantly embedded in our memory and consciousness. A film that has already given way to new images in the 
consciousness is not as present in the discussion, and this can quickly serve to make a discussion vague. This is why it is advisable to select a short film for the theme of the conversation during a lesson on film education. Every now and then, however, we take the experience that we have gained while working on short films and focus on a more demanding task - a discussion about a full feature film.

\section{Extract 5 - Introduction to film}

An introduction is an important step in the viewer's acceptance of a film. However, the introduction should never include any information disclosed in the film or explanation as to the idea behind the film. This type of introduction interferes with viewers' film experience and reduces their level of activity. The introduction should prepare viewers to follow the film and establish its message.

Different age groups demand different types of introduction before watching a film. For younger viewers, it is sufficient if we manage to create an appropriate mood, which then influences their interaction with the events in the film. This mood can be established through talking about similar events that they have experienced or that they have heard about from the press, radio or television. The introduction for older children, teenagers and youth can also include a discussion about genre, a debate about the style of film-making to which the film belongs, information on the author or drawing attention to certain elements of film language and expression that are important for the film.

\section{The course of the conversation}

In the first phase of the discussion, participants should gather impressions, tell us what has emotionally moved them and describe their feelings. While responding to what they have seen, they are organizing their impressions. This phase is the most spontaneous part of the discussion, and during this phase, we try to establish what the film has left behind within each individual. The person leading the discussion does not participate in this phase of the discussion, but tries to encourage the participants in the debate to share what they have experienced. During this phase, we are not searching for the meaning behind the feelings and emotions, for we are trying to develop viewers' observation and perception skills.

In the second phase of the discussion, we define the film's subject and try to ascertain how the themes of the film are presented. We organize our impressions, clarify our feelings, emotions and thoughts, and try to find the reasons behind them. The reasoning should emerge from the film. We isolate those parts of the film that are essential for the viewers, and link them into the sense of a whole. At this point, the leader of the discussion participates in the discussion as an equal member of the group. During the third phase, the triangle that one can draw between the viewer, the film and the wider frame of life starts to open up, and we are able to start discovering the message of the film. We hear somebody else's experience and compare it to ours, and by comparing the two, a new life experience is created. We make judgements and deductions. The more aesthetically effective the work is, the greater it influences the formation of this experience. All of the important statements in a discussion, including those of an ideological nature, have to be supported by reasoning that stems from the film we are discussing, and the film should also validate all associations that are made. The search for validation outside the film is inappropriate and leads to a thesislike discussion about the film, by which we separate the film's content from its form 
of communication. The discussion thus quickly becomes vague, and potentially even moralizing.

The individual should explain why certain associations appear for them, and why they feel or think in a certain way. Through this process, we start teaching students to begin substantiating their statements, recognizing emotions and forming a rational relationship with them. We should analyse the way in which the expressive qualities of the film are used in order to achieve a certain effect in an age-appropriate manner, and the message of the film should also be defined in an age-appropriate way.

In the final phase, we do not merely recapitulate the message of the film: we should repeat the most important thoughts that were expressed, emphasize the especially interesting statements, and repeat the asked and yet unanswered questions. An unfinished discussion is not a failed discussion. By summarizing unsolved questions, we encourage the participants of the discussion to form their own view of filmic reality at a later stage, and this also encourages participants to establish their measures of evaluation.

During the discussion, we need to give each pupil the feeling that their experience of the film is equally as important and valid as the experience of others. This will give them the confidence with which they will find it easier to listen to how their fellow debaters experienced the film and to start a dialogue with them. Through this, students will be able to recognize the weaknesses in their statements, accept certain viewpoints of others and transform them into their own experience. Such discussions help form the habit of tolerant dialogue and learning through experience, and play an important role in opening up an individual to the world of others. They also help the individual create a viewpoint on the basis of other people's arguments and realizations.

\section{The role of the leader of the discussion}

In the discussion, the participants and the leader of the discussion are equals; the only way in which the leader differs from the others is in their experience. They can jointly decide to pursue one of the themes that they have identified, but before they do, they need to gather information regarding the experience of the film and the associations it triggered from everyone present in the group. Everybody is given equal space in the mosaic of feelings, emotions and thoughts that the film, as an aesthetic structure, inspired. Only if each and every individual participates in the discussion can the new experiences be a result of creativity and give rise to a new quality appearing in the emotional and intellectual world of the group. The teacher no longer lectures and tries to teach the right way of watching a film; the teacher, with their general knowledge and experience, participates in the discussion and encourages pupils to independently research the film.

\section{Extract 6 - Spontaneity frees the mind}

If we consider film education to be an educational tool that can be used to form the intellectual and emotional worlds of young people in the easiest and most direct way possible, we must explore a comparison of two different ways of discussing film: analytical and affective. At the 1966 Mannheim conference of European film educators, my Belgian colleague Roland Biernaux explained the workings of the analytical method with the aid of the film The White Dove (Frantisek Vlácil, 1960), and the affective method with the use of the film Cleo from 5 to 7 (Agnès Varda, 1962). He showed that a passive attitude among the participants in a discussion resulted from the analytical method, and - in contrast - illustrated what is possible when the affective method is used to relax and activate the members of the group involved in the debate. I feel his 
argument would have been even more convincing if the films that served as examples were equally appropriate for the same age group. As it was, the first film (The White Dove) was aimed at children, while the second (Cleo from 5 to 7 ) was aimed at young people over 16 years of age.

Roland Biernaux stated that the analytical method stems from classic educational approaches: the leader prepares a precise schedule for the discussion, comes up with the questions and compares various viewpoints in order to arrive at an appropriate final opinion. The questions that they pose originate from their personal attitude to the film and their personal interpretation of its message. Here, the leader of the discussion wishes to make the participants in the discussion understand and accept their way of thinking. Biernaux also mentioned that this approach enables preparation without actually seeing the film: in order to prepare the questions, it is enough to have a good and detailed review of the film. The questions limit the discussion and often alienate the thoughts of the participants from what is important to them, as these aspects of their experience might not fit within the overriding concept that has been set for the discussion. With this, we destroy the interest in discussion, which becomes fainter than we would have desired. A discussion led in this way often moves too far from the interests and experiences of the viewers and fails to yield good results.

The affective method asks a single question: What are your impressions of the film that you have just seen? This enables free thinking, doubts, agreement or rejection of the film. It establishes a lively debate among the group, as participants are able to establish their relationships with the film. They can seek and discover the value of the film through shared impressions, as well as ascertain the film's general human and artistic value. If we believe that every viewer is also the co-creator of the film, who gives it its true value, it is this type of conversation that makes it possible for the film to truly come to life. This search, this shared discovery of the meaning, creates the image of the film for those participating in the discussion, who become involved in different ways. The discussion does not merely enable them to understand the film, it also helps them find a sense of their own artistic values. Most of all, it helps them develop their sensitivity and capability to feel these values, to weave them into their personal experience and to become active viewers, who will know how to receive the artistic message of any film.

This method can also be used to dissect the aesthetic value of the film. The path is somewhat longer and harder, but the results are stronger. Such a debate also helps the individual develop as a person, who will know how to look for true human values in everyday life.

\section{Translator's notes}

1 One of the Centres for Youth Culture that could be found throughout Yugoslavia and beyond.

2 Now renamed Zlin.

\section{Notes on the contributors}

Mirjana Borčić (born 1925, Ljubljana) is a film educator, editor, producer and creator whose work established new foundations for contemporary film education in Slovenia. With her practical work, she developed and nurtured children's and youth creativity, popularizing it in Slovenia and abroad, while her theoretical work brought an in-depth reflection on the meaning and purpose of film education, its different approaches, objectives and methods. She has received numerous awards for her long-time work in film education, which has left a lasting stamp on the field. 
Jamie Chambers is a lecturer in film and television at Edinburgh College of Art. He is the founding editor of the Film Education Journal and has worked as a film education practitioner with Understanding Cinema and 'Le cinéma, cent ans de jeunesse' since 2013. He is the curator of the Folk Film Gathering (the world's first folk film festival (www. folkfilmgathering.com)) and is the director of the award-winning, BAFTA-nominated films When the Song Dies (2012) and Blackbird (2013).

Petra Slatinšek has been actively contributing to the shaping of film education for children and youth in Slovenia since 2004. She founded two major film education projects: in 2005, the education programme for animated film, Elephant (Slon), and, in 2008, the film education programme Kinobalon at the Kinodvor Cinema. The Kinobalon programme received Europa Cinemas' Best Young Audience Activities Award for 2010. In 2013, Petra Slatinšek was elected to the board of the European Children's Film Association.

\section{Filmography}

Cléo de 5 à 7 (Cleo from 5 to 7, FR/IT 1962, Agnès Varda)

Holubice (The White Dove, CZ 1960, Frantisek Vlácil)

Piknik v nedeljo ([Sunday Picnic], YV 1968, Karpo Acimovic-Godina)

Ya kupil papu ([l Bought Daddy], RU 1963, llya Frez)

\section{References}

Borčić, M. (2014) Odstiranje pogleda: Spomini, izkušnje, spoznanja. Ljubljana: Javni zavod Kinodvor. Borčić, M. and Nakrst, M. (1984) Uresničevanje filmske vzgoje v osnovni šoli. Ljubljana: Dopisna delavska univerza Univerzum.

Slatinšek, P. (2020) 'Applying Alain Bergala's "three phase" model to the history and development of film education in Slovenia'. Film Education Journal, 3 (1), 77-85. 